\title{
Könyv a magyar nyelv ótörök jövevényszavairól
}

\section{András Róna-Tas - †Árpád Berta, West Old Turkic. Turkic Loanwords in Hungarian*}

Nyelvünk és az uráli rokon nyelvek török eredetü rétege egyetemista korom óta érdekel. Sokat foglalkoztam a magyar nyelv honfoglalás előtti elemeivel és azt követő két réteggel. A BENKŐ LORÁND föszerkesztésében megjelent Etymologisches Wörterbuch des Ungarischen szófejtő szótárban (EWUng.) közel 1300 szócikket írtam, és ennek többszörösét szerkesztettem meg. Az általam készített szócikkek az A-J szókezdetü anyagban valamennyi honfoglalás elötti (ősi eredetü és jövevény) elemünkre, továbbá A magyar nyelv történeti-etimológiai szótára (TESz.) ismeretlen eredetủ szóanyagára kiterjedtek, a K-ZS kezdetüben pedig a finnugor és a török szóréteget foglalták magukban.

Egyetemi oktatói ténykedésem során gyakran indítottam Bevezetés a turkológiába címü kollégiumot, amelyen felső éves finnugor szakos, illetve magyar szakos hallgatók vettek részt. A törökségi és az uráli népek kölcsönhatását a kezdetektől napjainkig áttekintettem. Mint ismeretes - a könyvészetet mellözöm - A. KANNISTO 550 tatár jövevényszót mutatott ki a vogulban, H. PAASONEN pedig 150 elemet az osztjákban, K. DONNER és NÉMETH GYULA tucatnyi - részben bizonytalan - törökségi kölcsönszót a szamojédban. Y. WICHMANN szerint mintegy 180 csuvas jövevényszó, CsúCS SÁNDOR szerint pedig közel 1400 tatár jövevényszó számolható a votjákban. A cseremisz és a mordvin nyelvben a török hatásról RÄSÄNAN, WICHMANN, illetve PAASONEN óta napjainkig folynak a vizsgálatok. M. RÄSÄNEN szerint 450-500 szó mutatkozik a cseremiszben. AGYAGÁsI KLÁRA készülő cseremisz szófejtő munkája nyilván jó néhány száz csuvas és tatár jövevényszót fog tartalmazni. Lényegében ugyanez a helyzet a mordvinban. A törökségi nyelvekbe az uráliakból ugyancsak egy sor jövevényszó került be. RÉDEI KÁROLY és RÓNA-TAS ANDRÁS 16 permi alapnyelvi elemet állapított meg a csuvasban. RÄSÄNEN a csuvasban 60 cseremisz jövevényszót mutatott ki.

A turkológia legfontosabb szakirodalmából természetesen szó esett a turkológia két hazai alapmüvéröl, GOMBOCZ ZOLTÁNnak a bolgár-török elemeinkről 1912-ben írott monográfiájáról és LIGETI LAJOSnak A magyar nyelv török kapcsolatai a honfoglalás előtt és az Árpád-korban címü kézikönyvéről (1986). Az utóbbi mủvet páratlanul sokoldalúnak, de kissé megszerkesztetlennek találtam, amelyben a szerző adatközlései, etimológiai állásfoglalásai olykor nem erősítik,

${ }^{*}$ Part I: Introduction, Lexicon $» \mathrm{~A}-\mathrm{K} «$.Part II: Lexicon $» \mathrm{~L}-\mathrm{Z} «$, Conclusions, Apparatus. Turcologica Band 84. Harrasowitz Verlag. Wiesbaden 2011. X + 618. lap, X+619-1494. lap.

A szóban forgó monográfia ismertetését eredetileg Hazai György turkológus készítette volna, de betegsége, majd halála miatt nem tudta befejezni. Köszönjük Zaicz Gábornak, hogy ezt a feladatot átvállalta. - A szerkesztőség. 
nem egészítik ki a más helyütt írottakat, írójuk azokat variálja is, sőt nem egyszer bizonyos ellentmondásokba keveredik.

1995-ben az MTA Nyelvtudományi Intézetében részt vettem a címben jelzett közel 1500 lapos munka 16 szavas A, Á betűs anyagának szakmai vitáján (a közreműködők között a következők szerepeltek: BERTA ÁRPÁD, CSÁKI ÉVA, KINCSES NAGY ÉVA és SÁNDOR KLÁRA). Tizenhat évet kellett várnunk az angol nyelvü kiadás megjelentetésére.

Az Előszóban (VII-X) a monográfia elsődleges céljaként RÓNA-TAS ANDRÁS a nyugati ótörök nyelv fogalmát jelöli meg. A nyugati ótörök nyelv korábbi nyelvek, illetve nyelvjárások szövetsége, amelyet hozzávetőlegesen az 5-12. század között az Urál hegységtöl és az Urál folyótól nyugatra beszéltek. A területeken sok más nemzetiség között éltek a magyarok is, az 5-9. századig, majd az 1241. évi mongol invázió idején a Kárpát-medencében. Az évszázadok során nyelvünkbe sok száz török jövevényszó került, amelyek elősegítik a két szerzőtől kutatott nyugati ótörök nyelv megközelítését. Második célja a munkának a török szófejtések ismételt vizsgálata, a harmadik pedig a magyar nyelv és a magyar nép történetének újraértékelése.

Az alkotás egy munkaközösség együttmüködése eredményeképpen született. A szerzőtárs a fiatalon elhunyt kiváló turkológus, BERTA ÁRPÁD (1951-2008), RÓNA TAS első tanítványainak egyike, a szegedi altajisztikai tanszék volt vezetője. A sokrétü könyvben ő írta hét betű kivételével valamennyi török eredetű magyar szavunk szócikkét (619-1008). Az elkészült szócikkeket KÁROLY LÁSZLÓ, a Mainzi Egyetem docense, a szerzők egykori diákja szerkesztette véglegessé (a címlapon a két szerző neve mellett ez áll: ,,with the assistance of László Károly”). Az 1494 lapos munka további részeit, fejezeteit RÓNA-TAS ANDRÁs készítette. Az etimológiai adatbázis összeállításában és a további feladatok elkészítésében, illetőleg tanácsadásban a munkatársak közé tartozott többek között LARS JOHANSON, PETER ZIEME, valamint BiACSI MÓNIKA, CsÁKI ÉVA, GULYÁS BORBÁlA, KEMPF BÉlA, KovÁCs ElŐD, LENGYEl ISTVÁN, NAGY ÉVA, SinKOVICS BALÁZS, SZATMÁRI SÁNDOR, VÁSÁRY ISTVÁN, a finnugristák közül HONTI LÁSZLÓ és BAKRÓ-NAGY MARIANNE. A mű nyers kézirata 2009 nyarára készült el, az előszót RÓNA-TAS 2009 novemberében írta. Az alábbiakban az egyes fejezeteket sorszámmal látom el.

1. A Bevezetés (3-49) az első fejezetben (3-17) áttekinti a nyelvünkre irányuló török nyelvi vizsgálódásokat MARTINUS FOGELIUStól HASAN ERENig. J. E. FISCHER volt az első, aki a magyar és a csuvas szavakat egybevetette. Az ugor-török háború kettős eredménye: 1. a magyar nyelv finnugor, így török eredetű szavaink jövevények, 2. a török eredetű magyar szavak jelentős része a csuvasra jellemző. GOMBOCZ ZOLTÁN monográfiája 231 lexémát sorol fel. NÉMETH GYULA elsősorban a honfoglalás utáni kun és besenyő hatást vizsgálta. BÁRCZI GÉZA szófejtő szótárában (SzófSz.) 228 szót sorolt török elemeink időrendileg első két kategóriájába. A BENKÖ LORÁND föszerkesztésével készült két etimológiai szótár (TESz., EWUng.) török szócikkeit KAKUK ZSUZSA, illetve - a név itt nem szerepel - ZAICZ GÁBOR írta, és e két munka lektora LIGETI LAJOS és RÓNA-TAS ANDRÁS volt. LIGETI és RÓNA-TAS véleményét e szótárak nem mindig fogadták el. LIGETI 
LAJOS jó fél évszázados turkológiai tevékenységének eredménye 1986-ban napvilágot látott monográfiája, amelyben összesen 280 török eredetủ magyar szóval számol. A külföldi szerzők közül FogELIUS mellett J. E. FISCHER és Ph. J. VON STRAHLENBERG nevét a finnugristák is jól ismerik. A török történeti lexikológia első fontos terméke KĀŠGĀRI müve 1077-ből (1. BROCKELMANN 1928). A töröktatár nyelvjárások összehasonlító szótára BUDAGOV alkotása (1869-1871). VÁMBÉRY ÁRMIN, W. RADLOFF, G. J. RAMSTEDT és A. J. JOKI munkái után három fontos forrást kell megemlítenünk: MARTTI RÄSÄNEN Versuch eines etymologischen Wörterbuchs der Türksprachen (1969-1971), különösen pedig GERHARD DOERFER négykötetes Türkische und mongolische Elemente im Neupersischen (1963-1975) és GERARD CLAUSON An etymological dictionary of pre-thirteenthcentury Turkish (1972) címü szófejtő szótárát. Az 1960-as évektől kezdődően megjelenő szovjet/orosz kiadványok köréből kiemelem Sz. A. SZTAROsZTYIN, A. V. DiBO és O. A. MUDRAK Leidenben napvilágot látott altaji etimológiai szótárát (2003). Végül megemlítem volt tanárom, a török HASAN EREN Türk dilimin etimolojik sözlüğü c. mủvét (1998).

2. A második rész a történeti háttérrel foglalkozik (19-39). A törökök (pontosabban a hunok, az avarok, a bolgárok, a kazárok stb.), az irániak (alánok), a gótok, a szlávok, a germánok (frank, gepida, longobárd) és a magyarok helyzetéről szól Kelet-Európában. A magyaroknak előbb neveiről olvashatunk (Turkoi, (H)ungarus, b̌́ğrd [baskír], mj̆gr [majgar, mad'ar]), majd a legrégebbi magyar vonatkozású írásos emlékekről, például a 10. század közepi De administrando imperio címü müről vagy a Gesta Hungarorumról (13. század eleje). A szlávoknak a Kárpát-medencébe való bevándorlása az avaroknál korábban történt meg. A honfoglalás idején a frank és a szláv vezető réteg mellett a lakosság főleg elszlávosodott avar volt. A honfoglalást követően a 11. századtól a besenyők, a 13.-tól pedig a kunok képviselték a magyarság mellett a török népeket.

3. A 3. fejezet A szókészlet szerkezete címet kapta, és tájékoztatóul szolgál a szótár használatához (41-49). Az ótörök jövevényszavakat lexikai másolatoknak (angolul copy) nevezi, és a magyar szókészlet török elemeinek az oszmán hatás előtti legteljesebb áttekintését jelöli ki célul. Ez magában foglalja a mai köznyelvet, a nyelvjárásokból (főleg a Kunságból) eredő szóelemeket, az archaikus szókészletet és néhány kihalt szót is. RÓNA-TAS és BERTA valamennyi vitatott és ismeretlen eredetủ magyar szóelemet is bevont a vizsgálatba. E téren a BENKÖ LORÁND által föszerkesztett két kézikönyvet (TESz., EWUng.) tekinti a munka (rövidítése alapján a WOT.) alapvető forrásának. A török szavak egy része maga is jövevény, e kérdéseket „E/T” kezdettel a török szavak etimológiája tartalmazza. A betürendes szótár természetesen mindenekelött a magyar szavak átvételének körülményeit, a különféle szómagyarázatokat vizsgálja meg, a bekezdést „E/H” formulával elindítva.

4. A szótár (51-1008) beosztása: 1. a magyar címszó, 2. rövid etimológiai utalás, 3. a török szóalakok, 4. a török szó etimológiája, 5. a magyar szó etimológiájának részletesebb kifejtése, 6. bibliográfia. Egy-két részletet kiemelek a szócikkek 
felépítéséből. Sajnálatos, hogy a magyar nyelvjárási szavak egy részét a munkához nem használhatták, mivel az Új magyar tájszótár (ÚMTsz.) Sz-Zs szókezdetü ötödik kötete 2010-ben jelent meg. Az etimológiát követően a szerzők közlik a szócikkhez tartozó és bizonyítható keleti ótörök („EOT”), a középtörök („MT”, ezen belül keleti és nyugati) és/vagy újtörök („NT”) alakot is. A lehetséges mongol adatot is megadják, a tunguzt viszont szinte soha. A szótárírás török szavainak vizsgálata során RÓNA-TAS és BERTA kísérletet tesznek egy új, modern török morfológiai összegezésre (RÓNA-TAS e munkát a szófejtő szótárt követő fejezetekben is folytatja). A nyugati ótörök nyelvek hatása eredményeként a magyar nyelv jelentős részben átalakította ősi ugor képzőinek müködését. A bibliográfia mindig idézi a BENKÖ-féle munkaközösség két szófejtő szótárát (TESz., EWUng.), és rendszerint LIGETI említett 1986-os összegzésének eredményeit. Itt megemlítem, hogy korábbi vizsgálataim szerint a TESz. és az EWUng. etimológiai állásfoglalásában átlagosan minden harmadik szóban eltér. Végül is 384 szó alak- és jelentéstani vizsgálata alapján készülhetett a nyugati ótörök nyelvváltozat történeti leírása. Óriási a lexikon török alapbázisa: a szerzők 75000 adatot használtak fel, köztük 5-12. századi ótörök és 12-17. századi középtörök adatokat (mintegy húsz, illetve harminc forrásból).

E monográfia lényegében kétkötetes betürendes szótára irigylésre méltó teljesítmény. A betűrendes jegyzék - szúrópróbaszerủen ellenőrzött - (szinte) minden egyes részletét indokoltnak tartom. A szócikkek értékelését nem tekintem feladatomnak, az új szófejtések megítélését magyar nyelvész, turkológus, iranista és finnugrista kollégáimtól, illetőleg egy új magyar etimológiai szótártól várom.

Már elöljáróban említem, hogy a mü Számadatok címü alfejezetében (14891490) a magyar nyelv ótörök és kun rétegével kapcsolatban nyelvészeink összefoglaló lexikográfiai munkáiban a következő tételszámokat adja meg:

$\begin{array}{ll}\text { GOMBOCz (1912) } & 212 \text { (+ } 19 \text { téves) } \\ \text { BÁRCZI (SzófSz.) } & 226 \text { (+ } 2 \text { téves) } \\ \text { BENKÖ (főszerk., TESz.) } & 224 \\ \text { LiGETI (1986) } & 277 \text { (+ } 3 \text { téves) } \\ \text { BENKÖ (fószerk., EWUng.) } & 325 \\ \text { RÓNA-TAS-BERTA (WOT.) } & 419\end{array}$

Vagyis az utolsó munkában összesen 561 török etimológiából 419 biztos, lehetséges vagy valószínű, és e szavaknak átadója 384 esetben egy nyugati ótörök nyelv. A lexikon 419 tagja között 72 ige található (17\%), a további 347 címszó (83\%) főnév, melléknév és határozószó (1143). Még egy körülménnyel számolnunk kell: nyelvünkbe nemcsak nyugati ótörök (vagy kun) elemek kerültek, hanem - hangalakjuk alapján - csekély számban keleti ótörök lexémák is.

Az alábbiakban megvizsgálom, hogy mely lexémákat sorolta a WOT. a török jövevényszó-állományba legújabb etimológiai szótárunkhoz, az EWUng.-hoz képest. Az utóbbi biztos, bizonytalan, illetve vitatott minősítésével szemben áll a WOT. biztos, lehetséges/esetleges (possible), illetve vitatott (debated) minősítése. 
Ha megtekintjük az EWUng. (és elsősorban a TESz.) szócikkekhez füződő bibliográfiai jegyzékét, úgy látjuk, hogy egy-egy szó korábbi ótörök eredeztetése (ismét) felmerül. Így az EWUng.-ban közel száz lexéma nem török jövevényszó: az ápol, bálvány, bárca, becsül, bíró, bog, bojt, boly, böjt, börtön, bükk, bün, csak, csata, csökönyös, dug, ék, erkölcs, eskü, gaz, gyanú, ? gyarapodik, gyenge, gyepü, gyertyán. gyilkos, gyöz, gyúl, gyülöl, igen, ijeszt, imád, ing, izzik, jász, káliz, kár, karakán, kazár, kebel, kelengye, kert, kéve, koldul, komor, könyv, köpcös, lék, orvos, sajt, sebes, serleg, sért, sík, sima, sió, sok, sör, süly, sürü, szál, szán², szár, szenderedik, szép, szín, szöcske, szüz, táltos, tanács, táplál, tár, tart, tatár, telek ${ }^{1}$, terem, torol, tót, tökél, tör, történik, törvény, üdül, ül, vejsze, vendég, ver ${ }^{l}$ és a zerge. E szavak közül a német nyelvü szófejtő szótárban ismeretlen eredetű a bárca, becsül, bojt, boly, börtön, bükk, bün, csak, erkölcs, gyanú, gyenge, gyepü, győz, gyúl, izzik, kebel, serleg, szár, szín, telek', terem, tör, történik, törvény, ül és a ver (a következő szavaknak a töve ismeretlen eredetü: ápol, gyilkos, gyülöl, ijeszt, imád, komor, köpcös, sebes, táplál, üdül). Megemlítem még, hogy az EWUng. címszavai között valószínüleg vagy biztosan finnugor eredetü a bog, dug, ék, lék, orvos, sért, sok, süly, szál, szép, szik, táltos, tart és a vejsze.

Nyugati ótörök elemeink között vannak végső soron idegen eredetü lexémák is (26 szót sorol fel a mü; 1124-1125). A legtöbbjük az iráni nyelvekből került az ótörökbe (balta, bálvány, bársony, bor, bors, jász, komló, ? tömény), de található köztük végső soron horezmi (káliz, sajt), alán (kert), perzsa (bese, böszörmény, örmény), görög (kerep, terem) vagy latin gyökerü (kazár) is. A szavak olykor indoeurópai (alma, ? kender) vagy végső soron kínai (gyöngy) eredetüek, néhány elemnek pedig ismeretlen a forrása (bátor, tatár, ? tót). Néhány esetben a nyugati ótörök jövevényszó török képzővel lett ellátva, így a csanak és a serleg szótöve kínai, a körtvély-é pedig kaukázusi eredetü. Néhány esetben a nyugati ótörök szóelem egy harmadik nyelv (leggyakrabban a déli szláv) közvetítésével került a magyarba, ilyen a bán fönév és a bér.

A magyar nyelv e munka szerint 384 nyugati ótörök jövevényszót tartalmaz. Amennyiben ebböl figyelmen kívül hagyjuk az 56 vitatott eredetü és a 38 csak lehetségesnek tekinthető elemet, összesen 290 szó marad, és e számnak több mint a fele képviselve van a mai csuvasban (1176).

5. A Következtetések (Conclusions) első fejezete A magyar nyelv történeti hangtana (1009-1069). Ez a rész elsősorban a következő kérdéseket vizsgálja meg dióhéjban: az ugor alapnyelv fonotaktikai szerkezete, az ugor alapnyelv rekonstrukciója, az ősugor mássalhangzók eredete és története, az ősugor mássalhangzófonémák változásai a korai ősmagyarban és az ómagyarban, az ősugor magánhangzók eredete és története, és végezetül: a magánhangzórendszer a korai ösmagyar kor végén. A proto-obiugor, a protovogul és protoosztják alakok kikövetkeztetését HONTI LÁsZLÓnak az első szótagi obi-ugor vokalizmusról és konszonantizmusról írott monográfiái $(1982,1999)$ és a RÉDEI KÁROLY által szerkesztett uráli etimológiai szótár (UEW. 1986-1991) alapján végzi el RÓNA-TAS. A protougor csillagos alakokat ő maga - nem a korábbi finnugor nyelvészek - következtette ki, és az ugor alapnyelv hangrendszerét és szókincsét igen megbízhatóan rekonstruálta. Össze- 
gezése újszerü és kitűnő. Egyrészt azért, mert a munka nem használta fel a KISS JENŐtől és PUSZTAI FERENCtől szerkesztett Magyar nyelvtörténetet (2005), másrészt pedig az első angolul írt szakmunka nyelvünk történetéről. Finnugor nyelvi példáiban és kikövetkeztetett (finn)ugor alapalakjaiban a finnugrisztikában használatos $j$ helyett a turkológiában ismeretes $y$ betüt használja (például PFUgr *nélyä '4', 1023), de a rendszerszerüség miatt ez elfogadható. Igen érdekes az egységes ugor nyelv felbomlása után az ősmagyar nyelvben ható erős és gyenge tendenciák feltérképezése és megkülönböztetése, valamint a korai ösmagyar és az ómagyar mássalhangzók történetének táblázatos összegezése (1036-1037). Az uralisztikában ritka a magánhangzók változásának viszonylag részletes taglalása, elsősorban azért, mert a legtöbb magánhangzó rendszerint megőrizte eredeti palatális, illetőleg veláris hangszínét. A protougor vokalizmus kikövetkeztetett hét elemének (PUgr $a$, $o, u, i, e, \ddot{a}$ és $\ddot{u})$ megadja PFUgr előzményeit és mai magyar fejleményeit (10591061). Behatóan vizsgálja az első szótagi magánhangzó-nyúlást és a nem első szótagi magánhangzórendszer, azaz itt az egyetlen redukált a [sva] történeti változásait. A korai ősmagyar kor végére 14 magánhangzót és öt kettőshangzót következtet ki.

6. A következő fejezet A nyugati ótörök nyelv és a magyar (1071-1146) címet viseli, és a nyugati ótörök fonológiai rekonstrukcióját a magyar alapján végzi el (mássalhangzók, magánhangzók, változások a magánhangzórendszerben), továbbá a morfológia (szószármaztatás, a nyugati ótörök igei szótövek morfológiai beágyazódása a magyarba) és a lexikológia jelentősnek érzett kérdéseit tárgyalja. RÓNA-TAS a korai ösmagyar nyelvet az 5-6. század elöttre, a török nyelvekkel való első kapcsolatok előtti időre teszi, a kései ősmagyar nyelvet, az intenzív magyar-török együttélés korszakát pedig a 6-10. századra. E fejezetben a nyugati ótörök fonológiai rendszerét rekonstruálja, a nyugati ótörök hangok változásait vizsgálja meg nyelvünkben. Például 49 ugor és török eredetű szóbelseji affrikátát tartalmazó szó alapján a nyugati ótörök /č/ fejleményeit láthatjuk a korai és a kései ősmagyarban, valamint a mai magyarban (1091). Az /1/ és az /r/ fejleményeit tárgyalva részletesen megvizsgálja a lambdacizmus és a rotacizmus kérdését is (1104-1114). Egybeveti és nagyon hasonlónak találja a protougor és a nyugati ótörök magánhangzók megterheltségét (1122). Közli az ugor eredetü első szótagi magánhangzók funkcionális megterheltségét is (1123). A nyugati ótörök denominális és deverbális képzett igéit behatóan tárgyalja (1125-1135), például:

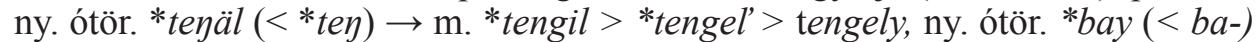
$\rightarrow \mathrm{m}$. báj, ny. ótör. *opura- $(<* o p) \rightarrow \mathrm{m}$. *oporo $>$ apor- $>$ áporodik, ny. ótör. ${ }^{*}$ sawur- $(<*$ saw- $) \rightarrow \mathrm{m}$. sawur-> szór. A török és a nem török eredetủ magyar igék fö különbségeit négy szabályba foglalja (1139-1140). A szóvég szempontjából megvizsgálja a török és a magyar igéket (1140-1142): 1. nincs járulékos képző, 2. az ikes igék csoportjába illeszkedés, 3-4. magyar deverbális, illetve denominális képző hozzájárulása, például ny. ótör. *dïg- $\rightarrow \mathrm{m}$. dug, ny. ótör. *kēč- $\rightarrow \mathrm{m}$. késik, ny. ótör. *äy- $\rightarrow$ m. enged, ny. ótör. *op- $\rightarrow \mathrm{m}$. ápol. A lexikológiai részben többek között a csuvas szókészlettel való egyezésekről és eltérésekről olvashatunk, és a fejezet végén RÓNA-TAS felsorolja azt a 115 nyugati ótörök szót, amelyeknek magyar fejleményei ismeretesek, de a csuvasból nem mutathatók ki (1145). 
7. A hetedik fejezet címe: Ki beszélte, hol és mikor a nyugati ótörököt? (1147-1176), és a kérdéses helyet, az időt, a müvelődési és gazdasági életet mutatja be. Ebben a részben - az idő vonatkozásában - számos érdekes, fonológiai és lexikológiai természetủ táblázatot találunk. Így a botanikai müszavak táblázata (1148), amely az azonos eredetü magyar, nyugati ótörök, alán és oszét müszavakat mutatja be, továbbá az affrikáták és szibilánsok kormeghatározó táblázata (1150), a nyugati és a keleti ótörök, valamint a csuvas szibilánsok 16 magyar szót tükröző táblázata bizonyos fonetikai helyzetben (1152) stb. Az állattenyésztés török jövevényszavai közül 44, a földművelés és a kertgazdálkodás szókincsét tekintve pedig $49(37+12)$ elemet sorol fel. Jelentős a halászati müszavak és a madárnevek közül a solymászat terminológiájába tartozó lexémák száma is (16, ill. 12). A hitélettel, a politikai és gazdasági élettel kapcsolatban 55 szóelemet lehet összeszámolni török elemként a magyar szókészletben. A nyugati ótörök nyelvet - választ adva az alapkérdésre - avarok, dunai és volgai bulgárok, kazárok beszélték, és fö változatát ogurnak nevezzük. Az ősmagyarságnak török kapcsolatai a Kubán-Don vidékén, majd pedig kétszáz éves etelközi tartózkodása idején voltak, mégpedig az említett 5-9. századig.

8. A 8-12. fejezet az Apparátus (Apparatus 1179-1494). A fejezet alfejezeteit bekezdésekbe szedve elemzem.

A Szólisták és mutatók (Lists and indices 1179-1369) fejezetcímei: 1. Valószínütlen etimológiák. 2-4. A keleti ótörök, a nyugati ótörök és a mongol szavak listája. 5. A (finn)ugor eredetü szavaink jegyzéke. Válogatás. 6. A finnugor és az ugor magyar szavak jegyzéke. 7. Problematikus finnugor és ugor etimológiájú magyar szavak. 8. A magyar tükörszavak (Hungarian semantical copies). 9. Az alán jövevényszavak listája a magyarban. 10. Kun jövevények listája. 11. A szláv szavak mutatója. 12. A magyar szavak mutatója.

A valószínütlen szófejtéseket (70 szó, 1179-1238) a könyv két részre osztja: 28-at részletesen - általában bő török szóanyaggal - elemez (például ló, nyak, nyár, nyargal, nyereg, ocsúdik, székely), 42-t csak utalásszerüen (például többek között a finnugor eredetü [? csepp], hattyú, ? irgalom, irt, ? ját, nyereg, öreg, [? por], ? sír, túr, továbbá az ismeretlen eredetü hatak, hír, hitvány, óv, pöcsik, sisak, szük, tilt, tok, toportyán-: toportyánféreg, tüdö, üsti, ver). E szavak értékelésében a BENKÖ-munkaközösség két szótárát rendszeresen idézi, és LIGETI alapmüvére is utal (kétszer is említi a por-nál a közlés hiányát [1233-1234] vagy a tözsér [1236] arab eredetét), illetőleg jelzi, ha e szóalak a munkában nincs megemlítve (kivéve például a hám, az ocsúdik, a túr vagy a ver címszót), vagy e múvet nem (eléggé vagy helyesen) veszi figyelembe (például az ispán, nándor, sír vagy a toportyán-: toportyánféreg esetében). A nándor alatti Nándorfehérvár régi alakja alighanem (Castrum) Nandoralbense (vö. FNESz. 1: 190).

A (finn)ugor eredetü magyar szavak jegyzéke kitünő válogatás az MSzFE., az UEW., a TESz. és az EWUng. felhasználásával (1272-1293). A jegyzék csak a biztos finnugor, illetve ugor etimológiákat közli, például „450. H tör 'dagger' $<$ PUgr *terz (not in POUgr) < PFUgr *terä". A számozásba ugyan bele vannak számolva az utalószavak is (összesen 15), de a „364. H róka 'fox', see ravasz” 
típusú utalások rendszerint önálló lexémára vonatkoznak. A korai ősmagyar változásainak vizsgálatára RÓNA-TAS összeállította a (finn)ugor szavak listáját is (1294-1316). A 465 tételből álló jegyzék (344 finnugor + 121 ugor) egyik elemeként idézem egy ösi szavunkat: „41. PFr *kala > PUgr kalə (POUgr *kūl > PVog

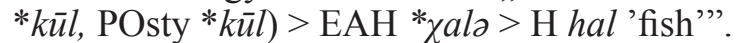

A problematikus (finn)ugor eredetü szavak között (1317-1323) - ha jól számolom - ötven szóalak található. Ezek a szakemberek számára csakugyan kérdésesek, nemegyszer példák egy-egy szó etimológiájának bonyolultságára. RóNATAS e fejezetet a korai ősmagyar történeti fonológiára alapozta. De ha ezeket a lexémákat egybevetjük az uráli és a magyar etimológiai szótárakkal, az eredmény csekély. E szavak között biztos eddigi etimológiák vannak (pl. fej, gyalog, gyökér), egyes szavak azért szerepelnek itt, mert hangtani, mások azért, mert jelentéstani nehézségek mutatkoznak a szófejtésben (például lel, mén, üt, ill. köcsög, $s z u ̈ l)$. Sőt egy sor lexémát a szerzőpár szójegyzékében már töröknek minősített (bog, hajó, ir, lék, orvos, sért, sima, sír fönév, süly, szép, szó, táltos, úr), vagyis ezek e fejezetben nem mondanak újat. Az ómagyar korból adatolható ma is gyakori szavaink között számos olyan van, amelyeknek nincs más szófejtése. Igy például az uráli etimológiai szótár elutasítja az imént említett táltos török eredeztetését - mint írja - „wegen der einwandfreien Ug[rischer] Zusammenstellung” (UEW. 895). Tehát e szótárak valószínú vagy bizonytalan etimológiáit valójában mind fel lehetett volna e fejezetbe venni, tudniillik ezek a szavak az EWUng.-ban szinte kivétel nélkül kérdőjelesek. Ezért - bár egy sor értékes megállapítás található a jórészt rövid szócikkek között - ezt a 7 oldalas részletet elhagytam volna. E részben nem kellő mértékben közli a forrásanyagot (például bogyó, harap). (A nyj. csuhé és a sima etimológiáját nem tudni, honnan idézi.) A szén-nek az itt olvashatónál jobb magyarázata is van (UEW. 494; EWUng. 1416). A tár hangutánzó-hangfestő eredete (EWUng. 1482) is vizsgálandó a finnugor mellett.

Az ótörök mintára átalakult magyar tükörszavak vizsgálatában (1324-1330) RÓNA-TAS egykori hallgatója, SCHMIDT SzONJA eredményeit hasznosította, aki elsősorban ERDŐDI, BERECZKI és LIGETI jelentős tanulmányait dolgozta fel. 35 szót, illetve szerkezetet sorol fel, amelyek török szavak szóelemenként való fordításából származó összetett (például ebihal, éjfekete, fokhagyma) vagy képzett szavak (például adó, házas, nincstelen, terhes, vagyon). A tükörszavakat jelentéstani szempontból négy csoportra osztja.

Az alán jövevényszavak és más középiráni elemek tekintetében (1331-1339) a szerző 34 lexémát sorol fel, amelyeknek túlnyomó többsége - pontosan 22 szóelem - már MUNKÁCSI BERNÁT fontos munkáiban is szerepel (például asszony, büz, egész, ezüst), és e szavaknak jelentékeny részét LiGETI (1986: 162-174) - és, mint olvashatjuk, több írásában HARMATTA JÁNOS - is közli. Emellett az elfogadhatatlan iráni elemeket - ugyancsak 34 szót - is felsorolja (például az üstök-öt) (1339). Itt adtam volna meg (1339) az Addenda részben közöltek helyett (1494) a zsineg kiegészítő magyarázatát.

A kun jövevényszavak a kun szavak kikövetkeztetett betürendjében szerepelnek (1340-1342). A köznyelvben ezek közül a következők jelentkeznek: bárca, buzogány, csödör, kalauz, kobak, koboz, komondor, kuvasz, özön, tábor, 
tözeg, azaz az itt felsorolt lexémáknak egyharmada. A szótári részben egyébként az átadó alakokat a szerzők kunként (nem ótörökként) jelzik.

Az idézett szláv eredetü szavak jegyzékét (1343-1344) követi a magyar szómutató (1345-1369). A magyar jegyzékben néhány szó több mint tízszer fordul elö a munkában (gyümölcsény, ivv, lé, sőreg, szúnyog). Feltünik itt a tulajdonnevek viszonylag magas száma. A szómutatóból hiányzik a Kiegészítések között tárgyalt (1491) béke és csámpás.

9. Az Irodalomjegyzéket (1371-1459) nagy élvezettel tanulmányoztam végig. Ez a monumentális bibliográfia legalább 1700 tételből áll. Tíz esetnél többször szerepel az idegen szerzők közül W. BANG, N. A. BASzKAKOV, G. CLAUson, G. Doerfer, N. Erdal, H. Eren, P. B. Golden, S. Kalużyński, Sz. G. Kluastornit, N. Poppe, O. Pritsak, W. RAdloff, G. J. RAMSTÄDt, M. RÄSÄNEN, T. TEKIN, A. ZAJĄCZKOWSKI és P. ZIEME. A magyar szakemberek sorában 20 fölött, a tételszám szerint rangsorolva: MUNKÁCSI BERNÁT, RÓNA-TAS ANDRÁS, NÉMETH Gyula, Pais Dezső, Ligeti lajos, Gombocz Zoltán, Palló Margit, Berta ÁrPÁD, BENKÖ LORÁND, BEKE ÖDÖN, MELICH JÁNOS, MOÓR ELEMÉR, BÁRCZI GÉZA. A jegyzékben U. KÖHALMI KaTAlin (1425) és N. SEBESTYÉN IRÉN (1454) munkái nem a helyes betürendben szerepelnek. A könyvészetbe bevettem volna még a Magyar nyelvtörténet mellett CsúCS SÁNDORnak a Die tatarischen Lehnwörter des Wotjakischen címü müvét is (Budapest, 1990).

10. A további fejezetek tartalma: 10. Rövidítések, 11. Térképek, 12. A számadatok (ismertetésem során már említettem), 13. Pótlások és javítások (1461-1494).

Összefoglalásképpen megállapíthatjuk, hogy a nyugati ótörökök vagy ogurok érintkezése a magyarokkal a korai ősmagyar kor végétől egészen a kései ősmagyar kor végéig tarthatott. RÓNA-TAS ANDRÁS és BERTA ÁRPÁD kitünő etimológiai munkát végzett, és RÓNA-TAS a mintegy ötszáz szófejtés feltárását követően a magyar alaktan történetét is áttekinti az ugor kortól a korai ősmagyar kor végéig. Az ugor alapnyelvet - annak fonológiáját és szókincsét - teljes egészében rekonstruálta. A nyugati ótörök hangrendszer leírása, az alaktani változások bemutatása is mintaszerüen sikerült. A nyugati ótörök adatok rekonstrukciója során a szerző megnyugtató módon tisztázza a török igék beépülését nyelvünkbe. GOMBOCZ és LIGETI felismerését igazolja a monográfia: a magyar nyelv régi jövevényszavai teljes mértékben szemléltetik az ótörök kori hangváltozásokat. A szintézis meggyőzően bizonyítja, hogy nyelvünk hangrendszere és szókészlete török hatásra nagy változásokon esett keresztül, ezzel szemben nyelvtanunk alig változott. Az igen jelentős ótörök hatás ellenére a magyar nyelv megőrizte finnugor alapsajátosságait az ugor egység felbomlásától egészen az ómagyar korig.

A RÓNA-TAS ANDRÁS vezetésével készült kézikönyv nemcsak régi török jövevényszavainkat vizsgálja meg, hanem egyúttal bemutatja - mozgásban és változásában - az átadó régi török és az átvevő ős-, illetőleg ómagyar nyelv hang-, alak- és jelentéstani rendszerét. A nagymonográfia egy sor kérdésben további kutatásokra hívja fel a társszakmák müvelöit. A szintézis tanulmányozása a magyar 
hangtörténet és lexika, a magyar történelem, a magyar ős-, gazdaság- és művelödéstörténet stb., a turkológia és egy sor más diszciplína müvelője számára annyira kötelező érvényünek látszik, hogy aligha túlzás: e tudományterületek szakemberei ennek az ismeretanyagnak a hiányában már napjainkban is bizonyos szakmai tájékozatlanságot árulhatnak el.

Az alkotás véleményem szerint a 21. század elejének legjelentősebb lexikológiai és nyelvtörténeti munkája.

Kulcsszók: ótörök jövevényszavak, nyugati ótörök nyelv, ős- és ómagyar hang-, alak- és jelentéstörténet, ótörök nyelvi hatás.

\section{Hivatkozott irodalom}

BRockelman, C. 1928. Mitteltürkischer Wortschatz nach Mahmūd al-Kāšgārīs Dìvān luyāt at-turk. Budapest-Leipzig.

BudAGOv, L. 1869-1871. Sravnitelnyj slovarj turecko-tatarskich narečij 1-2. Sankt Peterburg.

Clauson, G. 1972. An etymological dictionary of pre-thirteenth-century Turkish. Oxford. DOERFER, G. 1963-1975. Türkische und mongolische Elemente im Neupersischen 1-4. Wiesbaden.

EREN, H. 1999. Türk dilimin etimolojik sözlüğüu. Bizim Büro Basım Evi, Ankara.

EWUng. = Etymologisches Wörterbuch des Ungarischen 1-2. Hrsg. LORÁND BENKÖ. Akadémiai Kiadó, Budapest, 1993-1995.

FNESz. = KISS LAJOS, Földrajzi nevek etimológiai szótára 1-2. 4., bővített és javított kiadás. Akadémiai Kiadó, Budapest, 1988.

GOMBOCZ, ZOLTÁN 1912. Die bulgarisch-türkischen Lehnwörter in der ungarischen Sprache. Helsinki.

HONTI LÁSZLÓ 1982. Geschichte des obugrischen Vokalismus der ersten Silbe. Akadémiai Kiadó, Budapest.

Honti LÁszló 1999. Az obi-ugor konszonantizmus története. Studia Uralo-Altaica 9. Universitas Szegediensis de Attila József Nominata, Szeged.

KISS JENŐ - PUSZTAI FERENC szerk. 2005. Magyar nyelvtörténet. Osiris Kiadó, Budapest.

LIGETI LAJOS 1986. A magyar nyelv török kapcsolatai a honfoglalás előtt és az Árpádkorban. Akadémiai Kiadó, Budapest.

RÄSÄNEN, M. 1969-1971. Versuch eines etymologischen Wörterbuches der Türksprachen. 1-2. Lexica Societatis Fenno-Ugricae 17. Helsinki.

Starostin, Sz. A. - Dibo, A. V. - MudraK, O. A. 2003. An etymological dictionary of the Altaic languages $1-3$. Brill, Leiden.

SzófSz. = BÁRCZI GÉZA, Magyar szófejtó szótár. Budapest, 1941.

TESz. = A magyar nyelv történeti-etimológiai szótára 1-3. Főszerk. BENKÖ LORÁND. Akadémiai Kiadó, Budapest, 1967-1976.

UEW. = Uralisches etymologisches Wörterbuch 1-2. Hrsg. KÁROLY RÉDEI. Harrassowitz, Wiesbaden - Akadémiai Kiadó, Budapest, 1986-1988.

ÚMTsz. $=$ Új magyar tájszótár 1-5. Főszerk. B. LŐRINCZY ÉVA. Akadémiai Kiadó, Budapest, 1979-2010. 


\section{A book on Old Turkic loanwords in Hungarian \\ András Róna-Tas - †Árpád Berta, West Old Turkic. Turkic Loanwords in Hungarian}

This book by András Róna-Tas and Árpád Berta was published in 2011 by Harrasowitz. The handbook does not only explore early Turkic loanwords in Hungarian but it also presents, in their movements and changes, the phonological, morphological, and semantic systems of both Turkic and Proto- and Old Hungarian as source and target languages, respectively. The comprehensive monograph calls for further research from related disciplines in a number of different issues. Studying this synthesis appears to be obligatory for representatives of Hungarian historical phonology and lexicology, Hungarian ancient history, economic history, cultural history, etc., as well as Turkic studies and a range of other disciplines. The authors propose Old Turkic or Cumanian etymologies for 419 morphemes, significantly surpassing the number of entries in any earlier etymological dictionary. The paper gives a detailed chapter-by-chapter summary and evaluation of the book.

Keywords: Turkic loanwords, West Old Turkic, Proto-Hungarian and Old Hungarian historical phonology, morphology, and semantics, linguistic influence of Old Turkic.

ZAICZ GÁBOR

Pázmány Péter Katolikus Egyetem 